\title{
Determining the opinions and expectations of the local farmers about the potential impacts of kocaeli kandira food specialized Organized Industrial Zone, Turkey
}

\author{
Bahar AYDIN CAN ${ }^{1 *}$ (D), Sait ENGINDENIZ²
}

\begin{abstract}
This research analyzed the potential impacts of the establishment of Food Specialized Organized Industrial Zones on the region and its neighborhood. The villages of Kocakaymaz and Goncaaydin in Kandira district of Kocaeli province were included in the research, and the data obtained from 131 farmers through survey was used. In line with the data, the farmers were grouped as the farmers whose land in Kandira Food Specialized Organized Industrial Zone (FSOIZ) was expropriated (directly affected) and the farmers whose land in Kandira FSOIZ was not expropriated (indirectly affected), and then they were evaluated. For this purpose, both the socio-economic characteristics of the farmers included in the research and their opinions and expectations about the probable impacts of the establishment of Kandira FSOIZ on farmers' income, product pattern, raw material procurement, product marketing, employment and neighborhood were presented. The obtained results showed that, of the farmers, $71.76 \%$ were planning to engage in livestock production to meet the raw material needs of the FSOIZ and $90.07 \%$ desired their family members to work in Kandira FSOIZ (desirable and very desirable), which may prevent the young population in the establishments from leaving their village and have a positive impact on agricultural employment.
\end{abstract}

Keywords: agricultural production; food economics; organized industrial zone; agro-based industry; Kandira.

Practical Application: The study may set an example for other food specialized organized industrial zones planned to be established.

\section{Introduction}

Agricultural production makes a great contribution to the independent existence of countries. Likewise, in our age, industrialization has a great importance in reaching a higher level of welfare. The efforts of the world's most developed countries to obtain not only million tons of agricultural products but also more industrial products using more advanced technology emphasize the growing share of industry in the economies of our century. Today, one of the major problems of developing countries is to succeed in the race of development. To this end, developing countries follow the example of developed countries in their efforts and intend to become industrialized. The establishment of such zones in certain localities of the country and the development of both economy and industry of such localities allow for interregional balance and organized industrial settlement (Berberoglu, 1984).

Established for creating more organized industrial areas, ensuring the equal distribution of economic development to regions, contributing to the development of Small and Medium-Sized Enterprises (SMEs) and minimizing the environmental problems caused by industrialization, Organized Industrial Zones (OIZs) are a kind of industrialization method (Alacadagli, 2004; Cevik \& Alperen, 2009).

OIZs are spatial incentive instruments used for directing private sector industrial investments to certain localities, supporting and promoting existing investments and meeting the land requirements of developing industries. On the other hand, OIZs are, in general terms, production and settlement units where technical and general services are provided in a suitable area equipped with transportation, water, electricity, sewerage, banks, canteens, phone, internet, natural gas and first aid (Cam \& Esengun, 2011).

Organized Industrial Zones (OIZs) are among the best examples of specific development in our country. While many development models of foreign origin fail, OIZs, which are in harmony with our country's internal characteristics, structure and social characteristics, succeed in financial terms by creating an economic clustering.

If the benefits of specialization and the condition of food industry in our country are combined, it is seen that the most important area to contribute to today's development thrust is the establishment of Food Specialized Organized Industrial Zones (FSOIZ) (Eroglu, 2011), suggesting how important it is to examine the probable impacts of the establishment of Food Specialized Organized Industrial Zones.

Up until now, many studies have been conducted on Organized Industrial Zones both in Turkey and all around the world (Cinier, 1991; Ergulen, 1998; Falcke, 1999; Sammarra \& Biggiero, 2001; Ozer, 2002; Kaechele \& Dabbert, 2005; Ibrahimi, 
2006; Tokalioglu \& Kartal, 2006; Cetin \& Kara, 2008, York \& Munroe, 2010; Cam \& Esengun, 2011; Tok et al., 2011; Jain, 2012; Hsu et al., 2013; Ohlan, 2013; Koc \& Bulmus, 2014; Tanc \& Gokoglan, 2015; Civelek, 2015; Ozden, 2016; Dumansizoglu \& Doker, 2017; Ozkan \& Uyanik, 2018). However, no study has been made to determine the effects of Food Specialized Organized Industrial Zones on the region of establishment.

Kandira Food Specialized Organized Industrial Zone is the first and leading food specialized OIZ of our country. Although food industry is a traditional branch of industry in our country, no specialized OIZ has been established in this sector yet.

Besides, Kandira region is an agricultural zone of Kocaeli province. The region meets agricultural needs as much as possible with its arable land of approximately 55,000 hectares, grain production of 57,750 tons, livestock potential of 20,000 cattle, and 261 poultry houses.

Kandira district of Kocaeli province - i.e. the area of research has an important place in the agricultural production of Marmara Region. Kandira Food Specialized Organized Industrial Zone is expected to contribute greatly from the marketing of agricultural products in terms of logistics to the development of agricultural industry. Thus, revealing the opinions and expectations of the local agricultural producers about its impacts on the region may set an example for other food specialized organized industrial zones planned to be established.

For this reason, this research is of great importance in terms of assessing the probable impacts of the establishment of Kocaeli- Kandira Food Specialized Organized Industrial Zone for the producers and identifying the problems and determining the solutions.

The purpose of this research is to present the farmers' opinions and expectations about the probable impacts of the establishment of Kandira FSOIZ on product pattern, raw material procurement, product marketing, employment and neighborhood. In the research, first the farmers' socio-economic status was examined and then the producer data was analyzed, the local farmers' opinions and expectations about the probable impacts of the Food Specialized Industrial Zone were determined, and some suggestions were made.

\section{Materials and methods}

The main material of the research was the primary data obtained through survey from the farmers in the villages of Kocakaymaz and Goncaaydin in Kandira district of Kocaeli province. The research was based on the data related to the production period of 2013. However, surveys were conducted in 2014.

In the examination of the farmers in Kocakaymaz and Goncaaydin, where Kandira FSOIZ is located, they were grouped as the farmers affected directly (whose land was expropriated) and the farmers affected indirectly (whose land was not expropriated). According to the Kandira FSOIZ records, 127 farmers were affected by the FSOIZ (120 farmers from Kocakaymaz and 7 farmers from Goncaaydin) and 81 farmers were not affected by the FSOIZ (22 farmers from Kocakaymaz and 59 farmers from Goncaydin) (Kandira FSOIZ Directorate, 2011). In the scope of the research, a face-to-face interview was made and a survey was conducted using the complete count method with a total of 131 farmers who lived in the village and accepted to have an interview ( 47 farmers from Goncaaydin and 84 farmers from Kocakaymaz). In this way, 81 farmers affected by Kandira FSOIZ as a result of expropriation and 50 farmers not affected by Kandira FSOIZ as a result of non-expropriation were included in the research (Table 1).

In the analysis of the data obtained, first the socio-economic characteristics of the farmers were identified. At that stage, age and educational level, number of family members, availability and use of labor force, availability and use of land, and capital of farmers were analysed. In addition, survey data was evaluated in terms of the possible impacts of the establishment of Kandira FSOIZ on local farmers' production, branch selection, employment, land market and neighborhood as well as in terms of its support to the local farmers.

The then-current number of animals owned by the establishments subject to examination was calculated in Cattle Units (CU). The coefficient was taken as 1.00 for cows and heifers and 0.10 for sheep and goats (Acil, 1980).

In the research, among all attitude and behavior scales, 5 -point Likert Scale was used to find out the farmers' opinions about the goals of the FSOIZ and determine their viewpoints and attitudes about the socio-economic effects that the FSOIZ would have. In the Likert Scale, the intensity of attitude was scaled in such a way as to increase positively from 1 to 5 .

For the purpose of determining which factors (and to what extent) affected the farmers' choice of growing/not growing crops for Kandira FSOIZ, one of the logistic regression analysis methods - i.e. binary logistic regression analysis - was applied.

In logistic regression, the dependent variable is discrete and the predicted probability values range from 0 to 1 . The logistic

Table 1. The number of farmers whose land was affected/not affected by Kandira FSOIZ.

\begin{tabular}{|c|c|c|c|c|c|c|}
\hline \multirow{3}{*}{ Villages } & \multicolumn{6}{|c|}{ Establishments whose land was affected/not affected } \\
\hline & \multicolumn{2}{|c|}{ Affected } & \multicolumn{2}{|c|}{ Not affected } & \multicolumn{2}{|c|}{ Total } \\
\hline & Number of farmers & $\%$ & Number of farmers & $\%$ & Numberof farmers & $\%$ \\
\hline Goncaaydın & 4 & 8.51 & 43 & 91.49 & 47 & 35.88 \\
\hline Kocakaymaz & 77 & 91.67 & 7 & 8.33 & 84 & 64.12 \\
\hline General & 81 & 61.83 & 50 & 38.17 & 131 & 100.00 \\
\hline
\end{tabular}


regression model based on the cumulative logistic probability function is denoted as follows (Gujarati, 1998; Equation 1).

$$
P_{i}=F\left(z_{i}\right)=F\left(\alpha+\beta X_{i}\right)=\frac{1}{1+e^{-(z i)}}=\frac{1}{1+e^{-\left(\alpha+\beta X_{i}\right)}}
$$

$\mathrm{P}_{\mathrm{i}}=$ Probability of selecting a certain option by the ith individual, $\mathrm{F}=$ Cumulative probability function,

$\mathrm{z}=\alpha+\beta \mathrm{Xi}$,

$\alpha=$ Constant,

$\beta=$ Parameter to be predicted for each explanatory (independent) variable,

$\mathrm{X}_{\mathrm{i}}=$ The ith independent variable.

It was statistically tested whether or not there were between-groups differences in the research. For continuous variables, first a normal distribution test was made using the Kolmogorov-Smirnov test, and the variables with and without normal distribution were identified. A variance analysis (One Way Anova) was performed for the variables with normal distribution (Ozdamar, 2004).

\section{Results}

\subsection{Farmers' socio-economic characteristics}

Information about the socio-economic characteristics of the farmers is given in Table 2. According to the Table, the farmers whose land was affected were 58.89 years old, studied for 4.81 years, and had 40.63 years of experience in agriculture, 3.86 household size, a family labor force potential utilization rate of $26.27 \%, 6.37$ hectares of land, and an equity rate of $88.89 \%$, on average. On the other hand, the farmers whose land was not affected were 59.90 years old, studied for 4.36 years, and had 44.44 years of experience in agriculture, 3.17 household size 5.50 hectares of land, and an equity rate of $91.54 \%$, on average. In addition, $62.5 \%$ of the farmers were aged 55 and over.
In terms of land ownership, $48.66 \%$ had their own land, $17.14 \%$ were tenant, and $34.20 \%$ had joint ownership over their land.

\subsection{Probable impacts on the selection of branch of production}

The examination of the relationship between whether or not the farmers' land was affected and the crops they produced showed that the farmers whose land was affected mostly produced wheat and barley, respectively, and the farmers whose land was not affected mostly produced oat and wheat, respectively. In general, wheat was the most grown crop with 1.54 hectares on average. Other field crops grown by the farmers included hazelnut, walnut, eggplant, tomato, pepper, and lettuce.

In the subject to examination, the average number of animals per farmer was 5.41 for cattle and 0.96 for sheep and goats. The highest number of cattle per farmers (6.48) was encountered in the farmers whose land was not affected.

Upon the examination of the impact of the establishment of Kandira FSOIZ on the selection of production branch, it was found that, in general, they planned to grow the products needed by the FSOIZ because the FSOIZ would allow for the free circulation of agricultural products, develop packaging, storage and marketing methods, and boost the export.

As a result of the variance analysis conducted to examine the relationship between the number of animals owned by the farmers and planning to engage in livestock production for Kandira FSOIZ, the relationship was found to be statistically significant $(\mathrm{p}=0.000)$ (Table 3$)$. Those farmers with a higher number of animals planned to engage in livestock production for meeting the needs of Kandira FSOIZ. They stated that they planned to do so in the belief that Kandira FSOIZ would enable them to sell their products more easily and regularly.

For the purpose of determining which factors (and to what extent) affected the farmers' choice of growing/not growing crops

Table 2. Socio-economic characteristics of farmers.

\begin{tabular}{lcc}
\hline & $\begin{array}{c}\text { Farmer whose land was affected } \\
\text { (81 farmers) }\end{array}$ & $\begin{array}{c}\text { Farmers whose land was not affected } \\
(50 \text { farmers) }\end{array}$ \\
\hline Age (years) & 58.89 & 59.90 \\
Average period of education (years) & 4.81 & 4.36 \\
Agricultural experience (years) & 40.63 & 44.44 \\
Household size (person) & 3.86 & 3.17 \\
Family labor force potential utilization rate (\%) & 26.57 & 40.87 \\
Average land size (ha) & 6.37 & 5.50 \\
Average number of parcels & 14.11 & 14.56 \\
Equity rate (\%) & 88.99 & 91.54 \\
\hline
\end{tabular}

Table 3. Relationship between the number of animals owned by the farmers and planning to engage/not engage in livestock production for Kandira FSOIZ.

\begin{tabular}{|c|c|c|c|c|c|c|c|c|}
\hline \multirow{3}{*}{$\begin{array}{l}\text { Number of animals } \\
\text { (CU) }\end{array}$} & \multicolumn{6}{|c|}{ Planning to engage/not engage in livestock production for the FSOIZ } & \multirow{3}{*}{$\begin{array}{c}\mathrm{F} \\
\text { Value }\end{array}$} & \multirow{3}{*}{$\begin{array}{c}\mathrm{P} \\
\text { Value }\end{array}$} \\
\hline & \multicolumn{3}{|c|}{ Planning } & \multicolumn{3}{|c|}{ Not planning } & & \\
\hline & $\mathrm{n}_{1}$ & $\mathrm{X}$ & $\mathrm{S}_{\mathrm{d}}$ & $\mathrm{n}_{2}$ & $\mathrm{X}$ & $\mathrm{S}_{\mathrm{d}}$ & & \\
\hline & 94 & 5.89 & 4.957 & 37 & 2.08 & 2.793 & 19.403 & $0.000^{*}$ \\
\hline
\end{tabular}

$\mathrm{CU}=$ cattle unit; $\mathrm{n}_{1}=$ number of farmers planning livestock production; $\mathrm{n}_{2}=$ number of farmers not planning livestock production; $\mathrm{X}=$ mean; $\mathrm{S}_{\mathrm{d}}=$ standard deviation; $\mathrm{P}$ Value $=$ significance probability; F Value $=$ F statistic probability; ${ }^{*}$ significant if $\mathrm{p}<0.01$. 
for Kandira FSOIZ, the Binary Logistic Regression Model was applied as the Logistic Regression method. The variables that can affect the choice of growing/not growing crops for Kandira FSOIZ and their categories and descriptions as well as descriptive statistics are given in Table 4.

In the logistic regression analysis, an answer was sought to the questions "Is there any difference in terms of the impact on growing crops to meet the regional need when Kandira FSOIZ is established?" and "If yes, what is the rate". To this end, a dummy variable representing growing/not growing crops for Kandira FSOIZ was used as the dependent variable.
The variables indicating land size, age, educational level, number of animals owned, non-agricultural income and number of family members were included in the analysis as the factors affecting the dependent variable. The prediction model developed in relation to these variables is given in Table 5 .

In the predicted model, the probability of growing crops for Kandira FSOIZ for the Farmers with a land size between 2.5 and 5 hectares is 1.32 times higher than the farmers with a land size less than 2.5 hectares. In terms of the number of animals owned by the farmers, the probability of growing crops for Kandira FSOIZ for the farmers having less than 5 CUs is 5.58 times

Table 4. Variables used in the logistic regression model and their characteristics by group .

\begin{tabular}{|c|c|c|c|c|}
\hline Variable & Group & Description & Number & $\%$ \\
\hline \multirow[t]{3}{*}{ Land size } & Land $(0)$ & $>2.5$ ha & 27 & 20.61 \\
\hline & Land (1) & $2.5-5$ ha & 31 & 23.66 \\
\hline & Land (2) & $>5$ ha & 73 & 55.73 \\
\hline \multirow{2}{*}{ Age } & Age (1) & $25-45$ & 18 & 13.74 \\
\hline & Age (2) & $>45$ & 112 & 85.50 \\
\hline \multirow{4}{*}{ Education } & Education (2) & Primary & 15 & 11.45 \\
\hline & Education (3) & Secondary & 3 & 2.29 \\
\hline & Education (4) & High School & 1 & 0.76 \\
\hline & Education (5) & University & 1 & 0.76 \\
\hline $\begin{array}{l}\text { Number of animals } \\
\qquad(\mathrm{CU})\end{array}$ & Animal (0) & $<5$ & 67 & 51.15 \\
\hline \multirow{3}{*}{$\begin{array}{l}\text { Non-agricultural income } \\
\quad \text { (Turkish Lira) }\end{array}$} & Income (1) & 501-1000 & 95 & 72.52 \\
\hline & Income (2) & $1001-1500$ & 12 & 9.16 \\
\hline & Income (3) & $\geq 1501$ & 1 & 0.76 \\
\hline \multirow[t]{3}{*}{ Household size } & Person (0) & $<5$ & 105 & 80.15 \\
\hline & Person (1) & $5-7$ & 24 & 18.32 \\
\hline & Person (2) & $>7$ & 2 & 1.53 \\
\hline \multirow[t]{2}{*}{ Growing/not growing } & Growing (1) & Will grow & 102 & 77.86 \\
\hline & Growing (0) & Will not grow & 29 & 22.14 \\
\hline
\end{tabular}

CU: cattle unit.

Table 5. Results of logistic regression model (will grow $=1 /$ will not grow $=0$ ).

\begin{tabular}{|c|c|c|c|c|c|}
\hline Independent variable & Coefficient & Std. Error & Sig. & Wald statistic & Probability rate \\
\hline Land $(0)$ & 0.998 & 0.544 & $0.067^{*}$ & 3.363 & 2.714 \\
\hline Land (1) & 1.279 & 0.511 & $0.012^{* *}$ & 6.262 & 3.594 \\
\hline Age (1) & -1.735 & 1.052 & $0.099^{*}$ & 2.719 & 0.176 \\
\hline Animal (0) & 20.620 & 1.340 & $0.099^{*}$ & 0.000 & 9.017 \\
\hline Animal (1) & 18.900 & 1.340 & $0.099^{*}$ & 0.000 & 1.615 \\
\hline Income (1) & 20.161 & 4.019 & 1.000 & 0.000 & 5.702 \\
\hline Person (1) & -1.061 & 1.432 & $0.045^{*}$ & 0.549 & 0.346 \\
\hline Person (2) & -3.135 & 1.745 & $0.072^{*}$ & 3.230 & 0.043 \\
\hline $\mathbf{R}^{2}$ & 0.310 & & & & \\
\hline $\mathrm{X}^{2}$ & $29.610(p=0.01)$ & & & & \\
\hline
\end{tabular}

*significant for $0.10 ;{ }^{* *}$ significant for 0.05 . 
higher than those having 5-15 CUs. It is seen that the farmers in need of agricultural income are more willing to grow crops.

In terms of the number of family members, the probability of growing crops for Kandira FSOIZ for the families with 5-7 members is 8.05 times higher than those with 7 or more members. Since the farmers that engage in plant production form the majority in growing crops to meet the needs of Kandira FSOIZ, it is possible to say that land size has a significant impact. It is also possible to think that, urged by necessity, the farmers with a lower income level believe, by growing products for Kandira FSOIZ, they will not have difficulty in marketing their products.

\subsection{Probable impacts on employment}

The establishment of Kandira FSOIZ is expected to result in the creation of considerable employment opportunities in the locality. It was found that the companies in the region would need employees to work especially in production and marketing.

As a result of the variance analysis conducted to examine the relationship between the number of family members of the farmers and their desire for the employment of family members in Kandira FSOIZ, the relationship was found to be statistically significant $(\mathrm{p}=0.014)$ (Table 6$)$. The majority of the farmers with a higher number of family members leaned towards the employment of their family members in Kandira FSOIZ. The farmers stated that the establishment of Kandira FSOIZ would offer a job opportunity to many people and contribute to the regional economy.

\subsection{Probable impacts on marketing}

According to the findings, the farmers in the research region do not perform planned production and the regional capacity is not efficiently used in terms of agricultural area. $60.97 \%$ of the companies to be located in the FSOIZ plan to procure most of the raw materials they need from the producers in the region. The companies that will carry out activities based on animal production in general plan to perform mostly contract production.

The establishment of an organized industrial zone that is specialized in food and processes agricultural products is expected to provide an advantage in the stabilization of agricultural product prices, which change year by year and thus sometimes become disadvantageous to the farmer. As is known, commodity exchanges allowing for transparent price formation for agricultural products have not become widespread in our country. The farmers does not know the sales price of his/her product at the harvest time and cannot plan his/her future. If he/she does not have a place to store his/her product and has a perishable product, he/she sells it at the price set by the broker following the harvest and incurs a considerable revenue loss. Kandira FSOIZ is expected to provide a great opportunity to the farmer in avoiding such revenue losses. The companies to be located in the FSOIZ will execute a contract with the farmers. Thus, both the companies will guarantee their supply and the farmers will foresee the amount of revenue they will earn. That the companies to be located in the FSOIZ plan to perform contract production will make a significant contribution to the increase of agricultural production in the region.

It is known that, in the neighborhood of Kandira, there are people who have completed their education but are unemployed. Kandira FSOIZ will create job opportunities for those unemployed people, support employment and prevent young people from emigrating from the region.

In the region, some of the farmers conduct production activities without adequate technical information. The companies to be located in the FSOIZ will provide technical support to the farmers, leading to more conscious agriculture in the region.

\subsection{General opinions and expectations}

The answers given to the questions intended to find out the farmers' opinions, attitudes and expectations about Kandira FSOIZ were assessed.

Farmers' agreement with the goals of the FSOIZ was examined, and their opinions about the subject matter were presented. The frequencies, percentages and average points of their agreement with the statements are given in Table 7. Accordingly, of the farmers who "strongly agreed" with the goals of Kandira FSOIZ, $22.90 \%$ agreed to "Develop packaging, storage and marketing methods", $19.85 \%$ agreed to "Ensure the free circulation of agricultural products", and $13.74 \%$ agreed to "Boost the export through synergy". The average point of their agreement with the goals of the FSOIZ was 3.77 for "Develop packaging, storage and marketing methods" and 3.66 for "Ensure that the industry has common infrastructure and social facilities". That most of the average points are above 3 indicates the farmers agreed with the founding purpose of Kandira FSOIZ. Most of the producers think positively especially about the marketing of their products because the establishment of an organized industrial zone will enable them to sell their products without need for a broker.

Table 6. Relationship between the number of family members of the farmers and their desire for the employment of family members in Kandira FSOIZ.

\begin{tabular}{|c|c|c|c|c|c|}
\hline \multirow{2}{*}{ The desire for the employment of family members in the FSOIZ } & \multirow{2}{*}{$\mathrm{n}$} & \multirow{2}{*}{$\mathrm{X}$} & \multirow{2}{*}{$\mathrm{Sd}$} & $\mathrm{F}$ & \multirow{2}{*}{$\begin{array}{c}\mathrm{P} \\
\text { Value }\end{array}$} \\
\hline & & & & Value & \\
\hline Very undesirable & 4 & 3.25 & 1.258 & & \\
\hline Undesirable & 5 & 5.20 & 1.954 & & \\
\hline Desirable & 56 & 3.39 & 1.569 & & \\
\hline Very desirable & 62 & 3.89 & 1.883 & & \\
\hline
\end{tabular}

$\mathrm{n}=$ number of family members of the farmers; $\mathrm{X}=$ mean; $\mathrm{Sd}=$ standard deviation; $\mathrm{P}$ Value $=$ significance probability; $\mathrm{F}$ Value $=\mathrm{F}$ statistic probability; ${ }^{\star}$ Significant if $\mathrm{p}<0.05$. 
Table 7. Farmers' attitudes and behaviors in relation to agreement with the goals of Kandira FSOIZ .

\begin{tabular}{|c|c|c|c|c|c|c|c|c|c|c|c|}
\hline \multirow{3}{*}{ Goals } & \multicolumn{11}{|c|}{ Opinions $^{*}$} \\
\hline & \multicolumn{2}{|c|}{1} & \multicolumn{2}{|c|}{2} & \multicolumn{2}{|c|}{3} & \multicolumn{2}{|c|}{4} & \multicolumn{2}{|c|}{5} & \multirow{2}{*}{ Average } \\
\hline & $\mathrm{n}$ & $\%$ & $\mathrm{n}$ & $\%$ & $\mathrm{n}$ & $\%$ & $\mathrm{n}$ & $\%$ & $\mathrm{n}$ & $\%$ & \\
\hline $\begin{array}{l}\text { Develop packaging, storing and } \\
\text { marketing methods }\end{array}$ & 6 & 4.58 & 11 & 8.39 & 20 & 15.27 & 64 & 48.86 & 30 & 22.90 & 3.77 \\
\hline $\begin{array}{l}\text { Ensure that the industry has common } \\
\text { infrastructure and social facilities }\end{array}$ & 3 & 2.29 & 16 & 12.21 & 18 & 13.74 & 80 & 61.07 & 14 & 10.69 & 3.66 \\
\hline $\begin{array}{l}\text { Support the procurement of low-cost } \\
\text { and high-quality raw materials }\end{array}$ & 3 & 2.29 & 17 & 12.98 & 19 & 14.50 & 79 & 60.31 & 13 & 9.92 & 3.63 \\
\hline Boost the export through synergy & 5 & 3.81 & 15 & 11.45 & 28 & 21.37 & 65 & 49.62 & 18 & 13.74 & 3.58 \\
\hline $\begin{array}{l}\text { Develop agricultural products } \\
\text { processing industry }\end{array}$ & 3 & 2.31 & 22 & 16.92 & 17 & 13.08 & 79 & 60.77 & 9 & 6.92 & 3.53 \\
\hline $\begin{array}{l}\text { Increase the competitive power of } \\
\text { agricultural products }\end{array}$ & 5 & 3.82 & 16 & 12.21 & 34 & 25.95 & 64 & 48.86 & 12 & 9.16 & 3.47 \\
\hline $\begin{array}{l}\text { Maintain the level of agricultural } \\
\text { revenue, raise the standard of living } \\
\text { for agricultural employees }\end{array}$ & 5 & 3.82 & 29 & 22.14 & 18 & 13.74 & 67 & 51.14 & 12 & 9.16 & 3.40 \\
\hline
\end{tabular}

$\mathrm{n}=$ number of farmers; $\left.{ }^{*}\right)$ : 1- Strongly disagree, 2- Disagree, 3- Neither agree nor disagree, 4- Agree, 5- Strongly agree.

\section{Discussion and conclusion}

Agricultural lands are the primary natural economic assets in Kandira district of Kocaeli province. Most of them are suitable for marginal agriculture. However, given the fact that the majority of them are not used in agricultural production, this OIZ project, which the investor companies try to realize in Kandira district using their own financial resources, will create an opportunity for Kandira district.

Being a food industry-based initiative in the Eastern Marmara Region, Kandira FSOIZ will serve as a model for our country. As the food industry develops, the agricultural sector will revive and the farmers' revenues will experience a considerable increase. As is known, young people are unwilling to engage in farming. The main reason is that they think agricultural production has a low profit. However, with the development of food industry and the increase in the need for agricultural raw materials, the scale of agricultural production will get larger, resulting in an increase in agricultural revenues. In return, increasing agricultural revenues will make young people become more willing to do agricultural production.

The establishment of an organized industrial zone that is specialized in food and processes agricultural products is expected to provide an advantage in the stabilization of agricultural product prices, which change year by year and thus sometimes become disadvantageous to the farmer.

The companies to be located in the FSOIZ will execute a contract with the farmers. Thus, both the companies will guarantee their supply and the farmers will foresee the amount of revenue they will earn.

According to the findings, the farmers in the research region do not perform planned production and the regional capacity is not efficiently used in terms of agricultural area. The companies to be located in the FSOIZ plan to procure most of the raw materials they need from the producers in the region, leading to an increase in contract production.

It is known that there are people in the neighborhood of Kandira who have completed their education but are unemployed. Kandira FSOIZ will create job opportunities for those unemployed people and prevent them from emigrating from the region.

In the region, some of the farmers conduct production activities without adequate technical information. The companies to be located in the FSOIZ will provide technical support to the producers, leading to more conscious agriculture in the region.

As a conclusion; today, the world's population grows rapidly. The use of existing resources in the most efficient way before offering to consumers will allow our country to reach a position with a high competitive potential in the world trade. In consideration of the fact that the organized industrial zones to be established will enable the products of the farmers living in the rural areas of the Marmara Region, especially in Kocaeli and nearby cities, and engaging in agriculture and stockbreeding to be sold at fair prices under today's conditions and attain competitive power in the world trade, the realization of the Kandira FSOIZ project as soon as possible will have a significant impact in terms of the agriculture and stockbreeding sector.

\section{References}

Acil, F. (1980). Agricultural economy (No. 721). Ankara: Faculty of Agriculture Publications, Ankara University.

Alacadagli, E. (2004). Environmental management systems in organized industrial zones (Doctoral dissertation). Ankara University Institute of Social Sciences, Ankara. 
Berberoglu, G. N. (1984). The contribution of Eskisehir Organized Industrial Zone to the economy and industry of the city (Master's thesis). Anadolu University Institute of Social Sciences, Eskisehir.

Cam, H., \& Esengun, K. (2011). An investigation of organized industrial zones and the effects of business incentive policies on enterprises: practice in Osmaniye Organized Industrial Zone. Karamanoglu Mehmetbey University Journal of Social and Economic Researches, 13(21), 55-63.

Cetin, M., \& Kara, M. (2008). Organized industrial zones as an instrument of development: a research on Isparta Suleyman Demirel Organized Industrial Zone. Erciyes University Journal of Faculty of Economics and Administrative Sciences, 31, 49-68.

Cevik, C., \& Alperen, M. Y. (2009). A research on the social and working life of workers: a case study of Amasya Organized Industrial Zone. Dumlupinar University Journal of Social Sciences, 25, 221-236. http:// dx.doi.org/10.24181/tarekoder.450025.

Cinier, G. (1991). An investigation of organized industrial zones and environmental problems in terms of economy (Master's thesis). Anadolu University Institute of Social Sciences, Eskisehir.

Civelek, O. (2015). New generation organized industrial zones for industrial transformation. The Russian Academic Journal, 31(1), 46-52. http://dx.doi.org/10.15535/362.

Dumansizoglu, M., \& Doker, M. F. (2017). Spatial impacts of Gebze Organized Industrial Zone. Turkish Geographical Journal, 69, 89100. http://dx.doi.org/10.17211/tcd.319264.

Ergulen, H. C. (1998). An investigation of the role of organized industrial zone in the reconstruction of Kutahya economy (Master's thesis). Dumlupinar University Institute of Social Sciences, Kutahya.

Eroglu, H. (2011). Executive summary. Kandira-Kocaeli: Kandira FSOIZ Directorate.

Falcke, C. O. (1999). Industrial parks principles and practice. Journal of Economics Cooperation Among Islamic Countries, 20(1), 1-10.

Gujarati, N. D. (1998). Essential of econometrics. New York: Mc Graw Hill.

Hsu, M. S., Lai, Y. L., \& Lin, F. J. (2013). Effects of industry clusters on company competitiveness: special economic zones in Taiwan. Review of Pacific Basin Financial Markets and Policies, 16(3), 1-28. http://dx.doi.org/10.1142/S0219091513500173.

Ibrahimi, A. (2006). Subsidies provided to smes in Turkey and European Union and a practice on the SMEs operating in manufacturing industry in Eskisehir Organized Industrial Zone (Master's thesis). Anadolu University Institute of Social Sciences, Eskisehir.

Jain, A. (2012). An integrated model of subnational regional and urban economic development: framework of analysis applied to the city of
Casey, Victoria, Australia. Australasian Journal of Regional Studies, 18(2), 206-231.

Kaechele, H., \& Dabbert, S. (2005). Economic analysis of a multifunctional wetland management at the example of the conflict between farmers and nature conservationists in the Lower Odra Valley National Park. In Proceedings of the ICID 21st European Regional Conference. Frankfurt and Slubice-Germany and Poland: Frankfurt (Oder):International Commission on Irrigation and Drainage.

Kandira FSOIZ Directorate. (2011). Annual records. Kandira-Kocaeli: Kandira FSOIZ Directorate.

Koc, S., \& Bulmus, C. (2014). Determining the efficiency of organized industrial zones in regional economies: a case study of Kayseri and Sivas. Kirikkale University Journal of Social Sciences, 4(1), 177-215.

Ohlan, R. (2013). Pattern of regional disparities in socio-economic development in India: district level analysis. Social Indicators Research, 114(3), 841-873. http://dx.doi.org/10.1007/s11205-012-0176-8.

Ozdamar, K. (2004). Statistical data analysis with package Programs-1. Eskisehir: Kaan Publishing.

Ozden, E. (2016). Reconstructing organized industrial zones as an instrument of development. Megaron, 11(1), 106-124.

Ozer, Y. E. (2002). Organized industrial zones and their impact on urban development (Master's thesis). Dokuz Eylul University Institute of Social Sciences, Izmir.

Ozkan, O., \& Uyanik, I. (2018). Removal of metals and micropollutants in Mbr and Cas Systems in an industrial zone wastewater. Fresenius Environmental Bulletin, 27(1), 357-367.

Sammarra, A., \& Biggiero, L. (2001). Identity and identification in industrial districts. The Journal of Management and Governance, 5(1), 61-82. http://dx.doi.org/10.1023/A:1017937506664.

Tanc, A., \& Gokoglan, K. (2015). The impact of environmental accounting on strategic management accounting: a research on manufacturing companies. International Journal of Economics and Financial Issues, 5(2), 566-573.

Tok, H. H., Kurucu, Y., Peker, F., Ercal, E., \& Tok, E. (2011). A rural development model for the thrace region, organized agricultural zone. Journal of Environmental Protection and Ecology, 12(1), 228-239.

Tokalioglu, S., \& Kartal, S. (2006). Multivariate analysis of the data and speciation of heavy metals in street dust samples from the organized industrial district in Kayseri-Turkey. Atmospheric Environment, 40(16), 2797-2805. http://dx.doi.org/10.1016/j.atmosenv.2006.01.019.

York, A. M., \& Munroe, D. K. (2010). Urban encroachment, forest regrowth and land-use institutions: does zoning matter? Land Use Policy, 27(2), 471-479. http://dx.doi.org/10.1016/j.landusepol.2009.06.007. 